\title{
ASSESSMENT OF THE NUTRITIONAL STATUS FOR PRESCHOOL CHILDREN IN JORDAN
}

\author{
(Received:17.8.2009)
}

\author{
By \\ A. Y.A. Al-Rewashdeh \\ Department of Nutrition and Food Technology, Faculty of Agriculture, \\ Mu'tah University, Mu'tah, Al-Karak, Jordan
}

\begin{abstract}
One hundred ninety four preschool children (106 boys and 88 girls) aged 63.5 months (62-65) from Alkarak and Assalt cities in Jordan participated in this study. The nutritional status of the children was assessed using anthropometry and dietary methods and compared with the available references. Four anthropometrics indices were calculated based on median of US- NCHS standard for attached age. Intakes of energy, macro and micro-nutrients by the children were measured and compared with DRIs. The four $\mathrm{Z}$ score anthropometric indices are: height/age(ht/age $\mathrm{Z}$ score), weight/heigt(wt/ht $\mathrm{Z}$ score), weight/age(wt/age $\mathrm{Z}$ score) and BMI/age $\mathrm{Z}$ score used to assess stunting, wasting, underweight and undernutrition statuses, respectively. The boys had higher indices and dietary intake than girls. The $\%$ of stunted children was about $17 \quad(15 \%$ for boys, $\% 18$ for girls), that of wasted children was about $15 \%$ (12\% for boys, $\% 17$ for girls), of underweighted children was about $22 \quad(20 \%$ for boys, $\% 24$ for girls), and of undernourished children was about 12 ( $\% 10$ for boys, $\% 13$ for girls). The children consumed inadequate diet. The deficiency in their diet was about - $24 \%(-24.1 \%$ for boys, $-24.2 \%$ for girls) for energy; $-37 \%$ ( $-34.7 \%$ for boys, $-39.0 \%$ for girls) for protein; $-33 \%$ ( $-29.3 \%$ for boys, $36.3 \%$ for girls) for seven vitamins ( A, C, Thiamin, Riboflavin, Niacin, Folate, B12) ; and $-36 \%$ ( $33.8 \%$ for boys, $-38.4 \%$ for girls) for four minerals ( Calcium, Iron, Zinc, Iodine). The deficit in vitamins intake ranged from $-25.8 \%$ for Folate to $-40.8 \%$ for $\mathrm{C}$ and in minerals intake from $-30.5 \%$ for iron to $-40 \%$ for zinc. The children received adequate dietary vitamin E, 6.9mg (about 99\% of DRI).
\end{abstract}

Key words: anthropometry, boys, girls, , nutritional status, preschool children

\section{INTRODUCTION}

Good nutrition is critical for the well-being of individuals. Food variety, quality, quantity and accessibility can deeply affect health. Early malnutrition, especially, inadequate intake of protein, vitamins and minerals may lead to linear growth retardation, a state that is associated with increased morbidity and mortality (Hennart et al., 1987; Golden and Golden, 1991; Prentice and Bates, 1994 and Idohou-Dossou et al., 2003) , and has subsequent consequences on motor performance and coordination (Benefice et al., 1999), cognitive function (Grantham-McGregor, 1984), time of menarche and normal reproductive performance (Galler et al., 1987), and adequate immune reactions and resistance to infections (Martovell et al., 1994). Growth retardation is highly prevalent in developing countries (De Onis, 1993 Martorell, 1995). Inadequate intakes of dietary energy and protein and frequent infectious are causes of growth retardation (Rivera and Martorell, 1988; Habicht et al., 1995; Rivera et al., 2003). The final height was positively correlated with the height at the age of five years, but some degree of catch-up growth occurred. However, children who continue to live in the same environment in which they became stunted experience little or no catch-up in their growth later in life (Satyanarayana et al., 1980 and 1981 and Simondon et al., 1998).

The period from one to six years of age is marketed by vast development and the acquisition of skills. During these years the appetite decreases and the children have decreased interest in food and an increased interest in the world around them. They develop food jags during this time. The prevalence of stunting, wasting and underweight among preschool children differed in the various regions of the world, with the lowest prevalence in Latin America and the highest in 
Asia (Victora, 1992; De Onis et al., 1993 and Frongillo et al., 1997).

Studies on growth and nutritional status have been well documented in the developed countries whereas there is hardly any large scale data in many developing countries where the malnutrition is prevalent (Gupta and Sexena, 1977 and Nwokoro et al., 2006). Nutritional assessment is feasible through the food habits of persons, determining the insufficiencies and then to be able to propose the best solutions to get the best results (Davis and Stegman, 1998 and Pourhashemi et al., 2007). Nutritional assessment involves the gathering and evaluation of data of person's nutritional status. This area consists of anthropometric, biochemical (laboratory), clinical and dietary measurements and nutritional indices.

In the present study, two methods were used to assess the nutritional status of preschool children, these are anthropometric and dietary measurements. The aim of this study was to evaluate the nutritional status of children in AlKarak and Assalt cities and to provide a baseline data for future research.

\section{MATERIALS AND METHODS}

The present study was carried out between September 2008 and March 2009. The data were collected from seven kindergartens (KG). Five KG located in Al-Karak city (118 Km south Amman, the capital city of Jordan; Longitude: 35 degree, $42 \mathrm{~min}$ and $18 \mathrm{sec}$ east; latitude: 31 degree, $11 \mathrm{~min}$ and $8 \mathrm{sec}$ north) and $2 \mathrm{KG}$ located in Assalt city (29 Km north east Amman city; longitude: 35 degree, $43 \mathrm{~min}$ and $25 \mathrm{sec}$ east; latitude: 32 degree, 2 min and $35 \mathrm{sec}$ north). At the beginning, the Food Frequency Questionnaire (FFQ) and a letter about the importance of the study were sent with children to their parents and the repeated 24hour recall of diet and anthropometric measurements were executed to children that filled their FFQ. A total of 194 preschool children (106 boys and 88 girls) aged 61 - 64 months participated in the study. The study participants were selected from 221 children received FFQ and reported the repeated 24 hour diet recall.

Anthropometry is a quantitative method and is highly sensitive nutritional status and it can be practical indicators of health, growth and development of infants and children (WHO, 1995 and Amuta and Houmsou, 2009). The following measurements were recorded to each child: body weight was measured without shoes and in light clothing using common health balance to the nearest $0.1 \mathrm{Kg}$; height was measured to the bare footed standing subjects to the nearest of $0.5 \mathrm{~cm}$ using a Physician scale. Anthropometric measurements were taken according to Lohman et al. (1988). Body Mass Index (BMI) was calculated as weight in $(\mathrm{Kg})$ divided by height in $\left(\mathrm{m}^{2}\right)$. The U.S. National Center for Health Statics (NCHS) standard for the classification of malnutrition was widely accepted and recommended by the World Health Organization (WHO, 1986). The next anthropometric indices using $\mathrm{Z}$ score criteria relative to the NCHS references were calculated, they are height- forage (ht/age) Zscore for stunting status, weightfor- height (wt/ht) Zscore for wasting status, and weight for age (wt/age) Zscore for undernutrition status. Children statuses were classified as severely, moderately, normal or above status if the Zscore was -3 or less, $>-3$ to $-2,>-2$ to +2 , or +2 or more, respectively.

Macro and micro intakes were obtained from repeated 24-hour diet recall written by children parents. They recorded their children food intake for three consecutive days, two weeks days (Monday and Wednesday) and one week end day (Friday). The average daily food intakes were calculated and the nutrients namely, carbohydrates, proteins, total fats, saturated fatty acids (SFA), monounsaturated fatty acids (MUFA), polyunsaturated fatty acids (PUFA), vitamins (A, E, C, thiamine, riboflavin, niacin, folate and $\mathrm{B} 12$ ) and minerals (calcium, iron, zinc and iodine) were determined using Food Composition Tables (Pellet and Shadarvian, 1970, and HNIS,1988). Energy content of daily food was calculated by multiplying the daily eaten carbohydrates, proteins and fats (grams) by 4, 4 and 9 Kcal (Williams, 1985). Nutrient intakes were compared with Dietary References Intake values (FNB, 1997; 1998;2000;2001 and 2002).

Statistical analysis was performed using Systat 8.0 (SPSS Inc., Chicago, IL, USA) to compute the means, standard deviations (SD), Z score for ht/ age, wt/ ht, wt/ age and BMI/ age. For calculation the mentioned Zscores, the medians and $\mathrm{SD}$ of $\mathrm{WHO} / \mathrm{NCHS}$ standards were used. Student $t$-test was done in two directions at a significance level of 0.05 , and any difference between two means was considered statistically significant if $P$ value $<0.05$.

\section{RESULTS}

Table (1) shows the means and SD of height, weight and BMI of 106 boys and 88 girls and the comparison between these measurements and match median for age of NCHS standards. 
Data showed that the boys were significantly had higher weight and nonsignificantly higher height and BMI than those of girls. Compared with NCHS, the boys and girls attained $93.9 \%$ and $94.2 \%$ for height, $85.9 \%$ and $85.4 \%$ for weight and $99.3 \%$ and $98.7 \%$ for BMI.

Data on the percentage distribution of boys and girls according to NCHS standards for ht / age (stunting), wt / ht (wasting), wt/ age (underweight), and BMI/age (undernutrition) are given in Table (2). It showed that the girls had high, moderate and lower normal results than the results of boys. The overall (severely and moderately) prevalence of stunting was about $15 \%$ and $18 \%$, of wasting was about $12 \%$ and $17 \%$ of wt/age was about $20 \%$ and $24 \%$ and of BMI/age was about $10 \%$ and $13 \%$ for boys and girls, respectively. Data also showed that about $2 \%$ of boys and $3 \%$ of the girls were meeting the criterion of overweight (BMI/age $\mathrm{Z}$ score $>2$ ).

Table (1): Means of height $(\mathrm{m})$, weight $(\mathrm{Kg})$ and body mass index (BMI)* of Preschool children.

\begin{tabular}{|c|c|c|c|}
\hline & $\begin{array}{c}\text { Actual (A) } \\
* *\end{array}$ & $\begin{array}{c}\text { References } \\
(\mathrm{R}) * * *\end{array}$ & $\begin{array}{c}\text { \% of + or - } \\
\text { of A over R }\end{array}$ \\
\hline $\begin{array}{c}\text { Height } \\
\text { Boys }\end{array}$ & $1.043 \pm 0.16$ & 1.11 & -6.1 \\
$\begin{array}{c}\text { Girls } \\
\text { Weight }\end{array}$ & $1.027 \pm 0.12$ & 1.09 & -5.9 \\
Boys & $16.5 \pm 0.20$ & 19.2 & -14.1 \\
Girls & $15.8 \pm 0.60$ & 18.5 & -14.6 \\
BMI & & & -0.7 \\
Boys & $15.2 \pm 0.32$ & 15.3 & -1.3 \\
Girls & $15.0 \pm 0.40$ & 15.2 & \\
\hline
\end{tabular}

*The Outlet's index- actual weight $(\mathrm{kg}) /$ height in meters squared (Lee and Nieman, 2003).

** Mean weight of boys was significantly higher than that of girls: $P$-value $<0.05$

*** References of height $(\mathrm{m})$, weight $(\mathrm{Kg})$ and BMI for age (NCHS Standards).

Energy and protein intakes and requirements are presented in Table 3. This table shows that boys significantly received more energy and protein than girls. Both sexes consumed low energy and protein on the base of DRI recommendations and on the base of their calculated requirements. The boys and girls consumed $1323 \mathrm{Kcal}$ and $1244 \mathrm{Kcal}$ of energy and $12.4 \mathrm{~g}$ and $11.6 \mathrm{~g}$ of protein. The energy intake was about of DRI recommendations (for boys and girls) $85 \%$ for boys and $81 \%$ for girls calculated energy requirements. The percentage of protein intake for boys and girls was about $65 \%$ and $61 \%$ based on DRI recommendations and about $79 \%$ and $77 \%$ on the base of calculated protein requirements.

Macronutrients intakes and their relative energy contribution (REC \%) in the total energy intake of children are given in Table (4). Data show that boys consumed more grams of carbohydrates (205), total fats (48.5) and protein $(12,4)$ than girls $(194,46.7$ and 11.6, respectively). The REC \% for carbohydrates and fats were higher and for protein was lower than the recommended. It was about $104 \%$ for carbohydrates, $113 \%$ for fats and $37 \%$ for protein for both sexes when taken together. Table (4) also shows that all childrens received more SFA (140\%) and MUFA(131\%) and less PUFA(70\%) than the recommended for REC\% of these fatty acids (10\% each).

Table (5) shows the children intakes of micronutrients. In general, boys received more micronutrients than girls, and both sexes consumed less than the recommended. The average intake deficiency of PUFA was $-33 \%$ and $-39 \%$ for $\mathrm{n}-6$ and $-58 \%$ and $-66 \%$ for $\mathrm{n}-3$ for boys and girls, respectively. For vitamins, the deficiencies in diets of boys and girls were $-33.5 \%$ and $-39.3 \%$ for vitamin A, $-39.2 \%$ and $-42.4 \%$ for vitamin $\mathrm{C}$ and $-26.5 \%$ and $-34.5 \%$ for five-Bcomplex vitamins (thiamin, riboflavin, niacin, folate,and B12). However, boys and girls received adequate dietary vitamin $\mathrm{E}$. They consumed about $99 \%$ of the recommended. Mineral deficiency in the diets of boys and girls was $-32.1 \%$ and $-36 \%$ for calcium, $-27 \%$ and $-34 \%$ for iron, $-40 \%$ and $44 \%$ for zinc and $-36 \%$ and -39.6 for iodine. The average deficit of these seven vitamins was about $-29.3 \%$ for boys and $36 \%$ for girls (about $-33 \%$ as average for both sexes), of these four minerals was about $-34 \%$ for boys and $-38 \%$ for girls (about $36 \%$ as average for both sexes).

\section{DISCUSSION}

Anthropometrics can be considered sensitive indicators of health, growth and development in infants and children. They are used to assess the size, proportion and composition of human body (WHO, 1995). The ultimate intention of nutritional assessment is to improve human health (Beghin et al., 1998). Malnutrition which refers to an impairment of health either from a deficiency or excess or imbalance on nutrients is a public health significance among children all over the world (Amuta and Houmsou, 2009). There were various indices based on anthropometry used to evaluate the nutritional status of the children (WHO, 1995). It has now been well established that the body mass index (BMI) is the most appropriate variable for nutritional status (Must et al., 1991; RollandCachera, 1993 and Amuta and Houmsou, 2009). To study the nutritional status of preschool 
children, two methods were used in this study; they were anthropometrics and dietary measurements. The means of height and weight of the studied children were found to be much inferior when compared to NCHS standards which are the reference data recommended by WHO. Children had about $94 \%, 85 \%$ and $99 \%$ of NCHS standards for height, weight and BMI for matched age. Noteworthy, the present BMI mean, which nearly matching the standard, cannot be strongly used as index for assessing the nutrition status of the studied children. Means of height, weight and BMI of boys were better than those of girls and came in accordance with NCHS standards for matched age. However, boys consumed more energy and macro and micro nutrients than girls and may resulted in their higher body measurements (Agrabar-Murugker, 2005; Leahy et al., 2008 and Briefel et al., 2009).

It was observed that the mean prevalence of severely and moderately of stunting (ht/age), which used as index of chronic malnutrition was

Table (2): Percentage of preschool children according to status of stunting, wasting, underweight and undernutrition.

\begin{tabular}{|c|c|c|c|c|c|c|c|c|c|}
\hline \multirow[t]{2}{*}{ Status } & \multirow[t]{2}{*}{ Gender } & \multicolumn{2}{|c|}{$\begin{array}{c}\text { Severely } \\
\text {-3 SD } \\
\text { Z score } \\
\end{array}$} & \multicolumn{2}{|c|}{$\begin{array}{c}\text { Moderately } \\
\text { >-3 to -2 SD } \\
\text { Z score } \\
\end{array}$} & \multicolumn{2}{|c|}{$\begin{array}{c}\text { Normal } \\
>-2 \text { to }>+2 \mathrm{SD} \\
\mathrm{Z} \text { score } \\
\end{array}$} & \multicolumn{2}{|c|}{$\begin{array}{c}\text { Over } \\
+2 \text { SD } \\
\text { Z score } \\
\end{array}$} \\
\hline & & NO. & $\% * *$ & NO. & $\% * *$ & NO. & $\%$ & NO. & $\%$ \\
\hline Stunting & Boys & 2 & 1.9 & 14 & 13.2 & 87 & 82.1 & 3 & 2.8 \\
\hline Height/Age & Girls & 2 & 2.3 & 14 & 15.9 & 70 & 79.5 & 2 & 2.3 \\
\hline Wasting & Boys & 3 & 2.8 & 10 & 9.5 & 91 & 85.8 & 2 & 1.9 \\
\hline Weight/Height & Girls & 4 & 4.5 & 11 & 12.5 & 70 & 79.6 & 3 & 3.4 \\
\hline Underweight & Boys & 4 & 3.8 & 17 & 16.0 & 84 & 79.3 & 1 & 0.9 \\
\hline Weight/Age & Girls & 5 & 5.7 & 16 & 18.2 & 65 & 73.9 & 2 & 2.2 \\
\hline Undernutrition & Boys & 2 & 1.9 & 9 & 8.5 & 93 & 87.7 & 2 & 1.9 \\
\hline BMI*/Age & Girls & 3 & 3.4 & 8 & 9.1 & 74 & 84.1 & 3 & 3.4 \\
\hline
\end{tabular}

*BMI: the Outlet's index - actual weight (kg)/ height in meter squared - (Lee and Nieman, 2003) Note: References of height/ age, weight/height, weight/age and BMI were the medians of NCHS standards. ** Percentages of hovs were sionificantlv lower than those of oirls $P$-value $<005$

Table(3): Energy (Kcal/day) and protein (g/day) requirements based on dietary reference intake (DRI) and body height and weight.

\begin{tabular}{|l|c|c|c|cc|}
\hline \multirow{2}{*}{ Characters } & \multirow{2}{*}{$\begin{array}{c}\text { Actual Intake } \\
(\mathrm{AI}) \mathrm{a}\end{array}$} & \multicolumn{2}{|c|}{ Reference Intake (RI) } & \multicolumn{2}{c|}{ \% of + or - of AI over RI } \\
\cline { 3 - 6 } & & DRI * & Calculated ** & DRI & Calculated \\
\hline Energy (Kcal) & & 1742 & 1565 & -24.1 & -15.1 \\
$\quad$ Boys & $1233 \pm 11$ & 1642 & 1541 & -24.2 & -19.3 \\
Girls & $1244 \pm 14$ & & & & -21.0 \\
Protein (g) & & 19.0 & 15.7 & -34.7 & -22.7 \\
Boys & $12.4 \pm 0.6$ & 19.0 & 15.0 & -39.0 & \\
Girls & $11.6 \pm 0.8$ & & & & \\
\hline
\end{tabular}

a : AIs of boys were significantly higher than those of girls: $P$-value $<0.05 . *$ : Recommendations of FNB, 2002; **: calculated on the base of actual height $(\mathrm{cm})$ multiplied by $15 \mathrm{Kcal} / \mathrm{cm}$ for energy requirements (Beal, 1970) and actual weight (Ko) multinlied hv $0.95 \mathrm{~g} / \mathrm{Ko}$ for nrotein reauirements (FNB. 2002).

Table (4): Macronutrients intake and their relative energy contribution (REC \%) in total energy intake of preschool children. *

\begin{tabular}{|c|c|c|c|c|c|c|c|c|}
\hline \multirow[t]{2}{*}{ Nutrients } & \multicolumn{2}{|c|}{ Actual Intake (g)a } & \multicolumn{2}{|c|}{ REC\% (A) } & \multicolumn{2}{|c|}{$\begin{array}{c}\text { Ref. REC\% } \\
(\mathbf{R}) * *\end{array}$} & \multicolumn{2}{|c|}{$\begin{array}{c}\% \text { of }+ \text { or }- \text { of } A \\
\text { over } R\end{array}$} \\
\hline & Boys & Girls & Boys & Girls & Boys & Girls & Boys & Girls \\
\hline Carbohydrates & $205 \pm 2.4$ & $194 \pm 3.6$ & 62.0 & 62.5 & 60 & 60 & +3.3 & +4.1 \\
\hline Total Fats & $48.5 \pm 1.3$ & $46.7 \pm 2.5$ & 34.3 & 33.8 & 30 & 30 & +14.3 & +12.6 \\
\hline SFA $^{1}$ & $20.9 \pm 1.0$ & $18.91 \pm 1.6$ & 14.2 & 13.7 & 10 & 10 & +42 & +37 \\
\hline MUFA $^{2}$ & $19.6 \pm 1.4$ & $17.8 \pm 2.1$ & 13.3 & 12.9 & 10 & 10 & +33 & +29 \\
\hline PUFA $^{3}$ & $10.0 \pm 1.2$ & $9.9 \pm 1.4$ & 6.8 & 7.2 & 10 & 10 & -32 & -28 \\
\hline Protein & $12.4 \pm 0.6$ & $11.6 \pm 0.8$ & 3.7 & 3.7 & 10 & 10 & -63.0 & -63.0 \\
\hline Total Energy Intake (Kcal) & $1323 \pm 11$ & $1244 \pm 14$ & 100 & 100 & 100 & 100 & - & - \\
\hline
\end{tabular}

*Total energy content (Kcal) of average daily food intake was calculated by multiplying the daily eaten carbohydrates, fats and protein (grams) by 4 , 9 and 4, respectively (Williams, 1985).**: REC\% for carbohydrates, total fat and protein the (Health and Welfare Canada Nutrition, HWCN, recommendation, 1990) and for SFA $^{1}$ (Saturated fatty acids), MUFA ${ }^{2}$ (monounsaturated fatty acids) and PUFA ${ }^{3}$ (polyunsaturated fatty acids) the REC\% on the base of $10 \%$ of total energy intake (Lee and Nieman, 2003). a : Actual intakes of carbohydrates, total fats, SFA, MUFA and protein of boys were significantlv higher than those of girls: $P$-value $<0.05$ 
about $17 \%$; of wasting (wt/hht), which used as index of current malnutrition was about $15 \%$ and of underweight (wt/age) was about $22 \%$ for boys and girls taken together. These data indicate to malnutrition among the study boys and girls and may be attributed to various factors such as body size at birth and the nutritional status of mothers

(Mozumder et al., 2000 and Sanghvi et al., 2001), mothers education (Islam et al., 1994 and Smith and Haddad, 2000). Father's education was an important factor that is significantly associated with underweight status among preschool children. Usually father is the main earner and decision maker of a family and so his high education level plays an important role to ensure better nutritional status of children (Rayhan and Khan, 2006). Inadequate intake of dietary energy and protein are well-known causes of growth retardation (Mora et al., 1981 and Habicht et al., 1995). Protein and fat are the two most important macronutrients with high impact on children growth and energy provision (Pourhashemi et al., 2007). The role of specific micronutrient deficiencies in the etiology of growth retardation has gained attention more recently (Allen, 1994; and Brown et al., 2002). Deficiencies of some micronutrients, such as iron, magnesium and zinc, result in anorexia (Lawless et al., 1994 and Clausen and Dorup, 1998). Therefore, these nutrient deficiencies also may contribute to growth retardation indirectly by reducing the intake of other growth-limiting factors, such as energy and protein. Inadequate zinc intake may be contributing to the high prevalence of stunting. This mineral deficiency was identified as a cause of stunting and delayed development in the Middle East in 1980s (Sandstead, 1991; Rivera et al., 2003 and Sarraf et al., 2005). Zinc deficiency occurs in diets low in rich sources zinc such as red meats and high in whole -grain cereals rich in fibre and phytate which decreases zinc absorption (Sandstead, 1998 and PDR Health, 2004). Inadequate dietary zinc was reflected as biochemical signs (Mahmoodi and Kimigar, 2001). The addition of animal foods to the food list of children was associated with markedly higher average concentration of serum zinc and may promote linear growth (Government of Kenya, 1999; Bwibo and Neumann, 2003 and Murphy and Allen, 2003). n-6 and n-3 PUFA, especialty linoleic acid, play a role in physical growth (Heird, 2001).
However, the present data show that the children received inadequate amounts of energy, protein, vitamins, minerals and PUFA and may resulted in growth retardation, especially in girls. The observed low growth indices compared with NCHS standards may be attributed to nutritional and socio-economic factors rather than genetic factors since many researchers (Tanner, 1961; Banik et al., 1973; Janes, 1974; Esiet, 1984; Nwokoro et al., 2006) reported that African Origin subjects residing in developed countries have growth standards comparably or even higher than those of NCHS standards.

The recommended dietary allowances (RDA) represent an establishment of planning and assessing dietary intake and are the levels of intake of essential nutrients considered to be adequate to meet the known needs of practically all healthy people (Pourhashemi et al., 2007). However, requirements differ with age and body size owning to differences in genetic makeup; with the physiology state of individuals growth rate; and with sex. In the present study, the children received about $76 \%$ (for both sexes) and $83 \%$ ( $85 \%$ for boys, $81 \%$ for girls) of their energy requirements and about $63 \%$ (65\% for boys, $61 \%$ for girls) and $78 \%$ (79\% for boys, $77 \%$ for girls) of their protein requirements on the basis of RDA and calculated requirements, respectively. These deficiencies, which accounted for about $24 \%$ energy and $37 \%$ for protein on the base of RDA, were however, noted in Senegale (Idohou-Dossou, 2003), in Bangladish (Rayhan and Khan, 2006), in Iran (Pourhashemi et al., 2007) and in India (Khandare et al., 2008). Although there is a great deal of evidence that the RDAs are too low for optimal health, the argument over whether to raise these levels in intense. However this dialogue, many people do not receive even today's lower allowances. Workers in nutrition field, generally agree, however, that people who consume less than $70 \%$ of an RDA are at risk for developing nutritional deficiency and these disturbing figures suggest that nutrient deficiencies may be common (Pourhashemi et al., 2007).

To study the dietary balance of the studied children, the macronutrient intakes and their REC\% in total energy intake were calculated and accordingly compared with the recommendations of HWCNR (1990), which $60 \%, 30 \%$ and $10 \%$ for carbohydrates, fat and protein, respectively. Based on the healthy recommendations, and to study the balance of dietary fat intake,the total fat intake was divided into three groups, SFA, MUFA and PUFA and the REC\% of each group was 
compared with the recommended REC\% (10\% each, Lee an Nieman, 2003). On the basis of their actual total energy intake, the children received more energy from carbohydrates $(+4 \%)$ and total fats $(+13 \%)$ and low energy from protein $(-63 \%)$ than the recommended balanced diet. Further, the children consumed more energy from SFA $(+40 \%)$ and MUFA $(+31 \%)$ and less energy from PUFA (-30\%) than the recommended dietary fat balance. frequently eat fat food products rich in sugar or fat or both and low in micronutrients (energy-dense foods), for example, confectionary, soft drinks, lollipop, and chips even for the main meals. Among bad dietary habits of the present studied children was abstaining from regular meals. They drunk more soft sugary drinks and it accounted for about $15 \%$ of total energy intake for most of them. The same observation was reported by leahy et al., (2008) and Briefel et al., (2009). As in most

Table (5): Micronutrients intake of preschool children

\begin{tabular}{|c|c|c|c|c|c|c|}
\hline \multirow{2}{*}{ Nutrients } & \multicolumn{2}{|c|}{ Actual Intake (AI)a } & \multicolumn{2}{|c|}{ Reference Intake* $(\mathrm{RI})$} & \multicolumn{2}{|c|}{$\%$ of + or - of $\mathrm{AI}$ over RI } \\
\hline & Boys & Girls & Boys & Girls & Boys & Girls \\
\hline${ }^{1} \mathrm{n}-6$ PUFA (g) & $6.7 \pm 0.5$ & $6.1 \pm 0.7$ & 10 & 10 & -33 & -39 \\
\hline${ }^{1} \mathrm{n}-3$ PUFA (g) & $0.42 \pm 0.01$ & $0.34 \pm 0.02$ & 1 & 1 & -58 & -66 \\
\hline Vitamins & & & & & & \\
\hline${ }^{2} \mathrm{~A}(\mathrm{mcg})$ & $266 \pm 8$ & $243 \pm 9$ & 400 & 400 & -33.5 & -39.3 \\
\hline${ }^{3} \mathrm{E}(\mathrm{mg})$ & $6.9 \pm 0.8$ & $6.9 \pm 0.9$ & 7.0 & 7.0 & -1.4 & -1.4 \\
\hline${ }^{4} \mathrm{C}(\mathrm{mg})$ & $15.2 \pm 1.1$ & $14.4 \pm 1.2$ & 25 & 25 & -39.2 & -42.4 \\
\hline${ }^{4}$ Thiamin (mg) & $0.45 \pm 0.03$ & $0.37 \pm 0.04$ & 0.60 & 0.60 & -25.0 & -38.3 \\
\hline${ }^{4}$ Riboflavin (mg) & $0.42 \pm 0.04$ & $0.38 \pm 0.03$ & 0.60 & 0.60 & -30.0 & -36.7 \\
\hline${ }^{4} \mathrm{Niacin}(\mathrm{mg})$ & $6.1 \pm 0.4$ & $5.7 \pm 0.6$ & 8.0 & 8.0 & -23.8 & -28.8 \\
\hline${ }^{4}$ Folate $(\mathrm{mg})$ & $156 \pm 6$ & $141 \pm 8$ & 200 & 200 & -27.0 & -29.5 \\
\hline${ }^{4} \mathrm{~B} 12(\mathrm{mg})$ & $0.82 \pm 0.02$ & $0.73 \pm 0.03$ & 1.2 & 1.2 & -31.7 & -39.2 \\
\hline Minerals & & & & & & \\
\hline${ }^{4}$ Calcium (mg) & $543 \pm 14$ & $512 \pm 16$ & 800 & 800 & -32.1 & -36.0 \\
\hline${ }^{4}$ Iron (mg) & $7.3 \pm 0.4$ & $6.6 \pm 0.5$ & 10 & 10 & -27.0 & -34.0 \\
\hline${ }^{4}$ Zinc (mg) & $3.0 \pm 0.2$ & $2.8 \pm 0.3$ & 5 & 5 & -40.0 & -44.0 \\
\hline${ }^{4}$ Iodine $(\mathrm{mcg})$ & $57.5 \pm 2.6$ & $54.4 \pm 3.1$ & 90 & 90 & -36.0 & -39.6 \\
\hline
\end{tabular}

$*$ Reference intake of 1, 2, 3, 4 and 5: dietary reference intake, FNB (2002, 2001, 2000, 1998 and 1997, respectively). a : Actual intakes all nutrients( but vitamin

E) of boys were significantly higher than those of girls: $P$-value $<0.05$

In comparison with their requirements (FNB, 1997; 1998; 2000; 2001), the boys and girls consumed low vitamins, namely A, C, thiamin, riboflavin, niacin, folate and $\mathrm{B} 12$. The average deficit of these seven vitamins was about $-33 \%$ (ranged from $-26 \%$ for niacin to- $41 \%$ for vitamin C) for boys and girls taken together and may due to low children intakes of foods from animal sources and vitamin $\mathrm{C}$ sources. On the contrary, the children received adequate vitamin $\mathrm{E}$ and that may due to high oil and fat intake. The children consumed low dietary minerals, namely calcium, iron, zinc and iodine. The average deficit of these four minerals was about $-36 \%$ (ranged from $-31 \%$ for iron to $-42 \%$ for zinc) for boys and girls taken together. The above mentioned data were doubtless indicating to inadequacy in childrens dietary vitamins and minerals. It was accounted about-35\% for mentioned seven vitamins and four minerals. However, the deficiency in these nutrients was higher in girls diet than in boys diet. In instance, this status of children's vitamins and minerals was a mirror of their foods. They populations, breakfast is the least important main meal in terms of energy and is frequently inadequate from the nutritional point of view. Out of 106 boys, 41 (39\%) and of 88 girls, 30 (34\%) received no breakfast, only tea or juice or milk. The most common habits for most of the tested children were eating sandwiches, especially falafel (made from fried chick-pea), seneora and thyme with olive oil, eating potato and corn chips, drinking more soft drinks, eating less food from animal sources (meats, endogenous organs, fish, dairy products). These habits resulted in high intake of fat and carbohydrates, low intake of protein, especially from animal sources, and low intake of micronutrients.

In the 1980s, the Nutrition Collaborative Research Support Program identified six micronutrients that were particularly low in the primarily vegetarian diets of schoolchildren in rural Egypt, Kenya and Mexico: vitamin A, B12, riboflavin, calcium, iron and zinc. Negative health outcomes associated with inadequate intake of these nutrients include anemia, poor growth, rickets, impaired cognitive performance, 
blindness, neuromuscular deficits and eventually death. Animal source foods are particularly rich sources of these nutrients, and relatively small amounts of these foods added to the plant foods can substantially increase nutrient adequacy as those snacks designed for Kenyan schoolchildren when milk and ground beef added to their diets (Murphy and Allen, 2003 and Bwibo and Neuman, 2003). However, here is a question, can we provide our children in Jordan like these snacks in the light of our knowledge that their parents, cannot present to them all nutrition requirement especially from animal sources which gained high prices in later years.

Nutrition status is a major determinant of the health and well being of children and inadequate diets are associated with poor nutrition. Children are the first consideration in development process because they are the most vulnerable and the crucial of human development. Early childhood constitute the most crucial period in life when the foundations are led for cognitive, social and emotional language, physical development and cumulative life long learning. Therefore, the lower values obtained from this study are suggestive of the need for the improvement in the nutritional status of preschool children in Jordan. As mentioned in the beginning, this study was executed in cities and gave general idea; it was the nutrition status of city children 'not good'. This idea implies that the nutrition status of village children may be at 'bad' form.

In conclusion, energy, protein and macronutrient deficiencies seem to be a more serious problem among the studied children. Increase in animal foods and fruits and vegetables is one suggestion for improving the nutritional status of the children which requisite enhancing nutrition knowledge of parents and imply the important role of government in aiding the families especially in times of the raised prices, and in encouraging the animals farming.

\section{REFERENCES}

Agrabar - Murugkar D.( 2005). Nutritional status of Khasi school girls in Meghalaya. Nutr. 21: $425-31$.

Ahmed T. and Islam S. (1984). Impact of socioeconomic condition and maternal education on nutritional status of children. Dhaka Shishu Hospital J. September, 1 - 6.

Allen L. H. (1994). Nutritional influences on linear growth: a general review. Eur. J. Clin. Nutr. 48: S75-S89.
Amuta E. U. and Houmsou R. S.(2009).Assessment of nutritional status of school children in Makurdi, Benue State. Pakistan Journal of Nutrition 8 (5): 691 - 94.

Banik N.D.; Krishna R.; Bakshi A. and Tasker, A.D. (1973). Growth pattern of Indian school children in relation to nutrition and adolescence. Ind. J. Pediat., 40: 173 - 79.

Beal V.A. (1970). Nutritional Intake. In McCammon RW, ed: Human Growth and Development, Spring field, I11, Charles C Thomas.

Beghin I.; Cap M.R. and Dujardin B. (1998). A guide to nutritional assessment. Geneva, Switzerland: World Health Organisation.

Benefice E.; Fouere T. and Malina R.M. (1999). Early nutritional history and motor performance of Senegalese children, 4-6 years of age. Ann. Hum. Bio. 26, 443-55.

Briefel R., Wilson A. and Gleason P.(2009). Consumption of low- nutrient, energy- dense foods and beverages at school, home and other locations among school lunch participants and nonparticipants J.Am. Diet. Assoc. 109 70S-90S.

Brook C.G. (1971). Determination of body composition of children from skinfold measurements. Arch. Dis. Child. 46, 182- 4.

Black M. M. (2003). Micronutrient Deficiencies and Cognitive Functioning. J. Nutr. 133: 3927S-31S.

Brown K. H.; Peerson J. M.; Rivera J. and Allen L. H. (2002). Effect of supplemental zinc on the growth and serum zinc concentrations of prepubertal children: a meta - analysis of randomized controlled trials. Am. J. Clin. Nutr. 75: 1062-71.

Bwibo N. O. and Neumann C. G. (2003). The need for animal source foods by Kenyan children. J. Nutr. 133: 3936S-40S.

Clausen T. and Dorup I. (1998) Micronutrients, minerals and growth control. Bibl. Nutr. Dieta. 54: 84-92.

Cryan J, Johnson R.K. (1997). Should the current recommendations for energy intake in infants and young children be lowered? Nutr. Today. 32:69.

Davis J.R. and Stegman C.A. (1998). The Dental Hygienist Guide to Nutritional Care. Philadelphia: WB Sunder. USA .

De Onis M.; Monteiro C.; Akre J. and Clugston G. (1993). The worldwide magnitude of protein - energy malnutrition: an overview from the WHO global data - base on child growth. Bull. WHO 71: 703-12. 
Edward A.; Frongillo Jr.; Mercedes O. and Kathleen M. P. (1997). Socioeconomic and demographic factors are associated with worldwide patterns of stunting and wasting of children. J.Nutr. 127: 2302-9.

Esiet A.E.( 1984). Weight of Nigeria children in Calabar. J. Trop. Pediat., 32: 218 - 24.

Frongillo E.A.; De Onis M. and Hanson K.M. (1997). Socioeconomic and demographic factors are associated with worldwide patterns of stunting and wasting of children. J. Nutr, 127,2302-9.

Galler J.R., Ramsey F.C., Salt P. and Archer E (1987). Long - term effects of early kwashiorkor compared with marasmus. I. Physical growth and sexual maturation. J. Pediatr. Gastroenterol. Nutr. 6, 841- 6 .

Golden B.E. and Golden M.H. (1991). Relationships among dietary quality, children's appetites, growth stunting, and efficiency of growth in poor populations. Food Nutr. Bull. 13, 105-9.

Government of Kenya. (1999). Anaemia and status of iron, vitamin A and zinc in Kenya. The 1999 National Survey Report. UNICEF, Nairobi, Kenya.

Grantham - McGregor S. (1984). Chronic undernutrition and cognitive abilities. Hum. Nutr. Clin. Nutr. 38C, 83-94.

Gupta V. and Saxena S. (1977). Nutritional status of school children in rural and urban areas of Bikaner West Rajasthan. Ind. J. Pediat., 44: $301-8$.

Habicht J. P.;Martorell R. and Rivera J. A. (1995). Nutritional impact of supplementation in the INCAP longitudinal study: analytic strategies and inferences. J. Nutr. 125: 1042S-50S.

Haider M. and Haider S.Q. (1984). Assessment of protein energy malnutrition. Clin. Chem. 30,1286- 99.

Hautvast J.L.; Tolboom J.J. and Kafwembe E.M. (2000). Severe linear growth retardation in rural Zambian children: the influence of biological variables. Am. J. Clin. Nutr. 71, $550-9$.

Health and Welfare Canada Nutrition Recommendation, HWCNR, (1990). Ottawa, Supply and Service Canada.

Heird W.C. (2001). The role of polyunsaturated fatty acids in term and preterm infants and breast feeding mothers. Pediator. Clin. North Am. 48, 173.

Hennart P., Beghin D. and Bossuyt M. (1987).Long - term follow - up of severe protein - energy malnutrition in Eastern Za1re. J. Trop. Pediatr. 33, 10-12.

Human Nutrition Information Service, HNIS, (1988). Provisional table on the content of omega-3 fatty acids and other fat components in selected foods, NHIS/PT-103, USDA.

Idohou - Dossou N.,Salimata W.; Amadou T. G., Cheikh S. S.; Babou, D.; Djibril C. Jean Pierre B., Philippe C., Daniel H. and Daniel L. (2003). Nutritional status of preschool Senegalese children: long - term effects of early severe malnutrition. Br. J. Nutr. 90, 1123- 32.

Islam M.A., Rahman M.M. and Mahalanabis D. (1994). Maternal and socioeconomic factors and the risk of severe malnutrition in a child: a case-control study.Eu. J. Clin. Nutr., 48: 416-24.

Janes M.D.( 1974). Physical growth of Nigerian Yoruba children. Tropical Geog. Med., 26: 389 - 398. Children from birth to the age of five West Afr. Med. J.,17: 118.

Juan A. R.; Christine H.; Teresa G., Lynnette N. and Armando G. (2003). The effect of micronutrient deficiencies on child growth: A review of results from community - based supplementation trials1. J. Nutr. 133: 4010S$20 \mathrm{~S}$.

Khandare A.L.,Siruguri1 V., Rao A. Venkaiah K., Reddy G .and Rao G.S. (2008). Diet and nutrition status of children in four tribal blocks of Thane District of Maharashtra, India (Nutrition Status of Children). Pakistan J. Nutr. 7 (3): 485 - 8.

Lawless J. W.; Latham M. C.; Stephenson L. S.; Kinoti S. N. and Pertet A. M. (1994). Iron supplementation improves appetite and growth in anemic Kenyan primary school children. J. Nutr. 124: 645- 54.

Leahy K. E.; Birch L.L. and Rolls B.J.(2008). Reducing the energy density of multiple meals decreases the energy intake of preschool-age children. Am. J. Clin. Nut. 2008 88: 1459-68.

Lee R.D. and Nieman D.C. (2003). Nutritional Assessment, $3^{\text {th }}$ ed. McGraw Hill Companies. New York.

Lohman T., Roche A. and Martorell R. (1988). Anthropometric Standardization Reference Manual. Human Kinetics, Champaigne, USA, SPSS

Mahmoodi M.R. and Kimiagar S.M. (2001). Prevalence of zinc deficiency in junior high school students of Tehran City. Biol. Trace Elem. Res. 81, 93-103. 
Martorell R. (1995) Results and implications of the INCAP follow-up study. J. Nutr. 125: 1127S-1138S.

Martorell R., Kettel K. L. and Schroeder D.G. (1994). Reversibility of stunting: epidemiological findings in children from developing countries. Eur. J. Clin. Nutr. 48, Suppl. 1, 45-57.

Mora J. O.,Herrera M. G., Suescun J., de Navarro L. and Wagner, M. (1981). The effects of nutritional supplementation on physical growth of children at risk of malnutrition. Am. J. Clin. Nutr. 34: 1885-92.

Mozumder A.B.; Barkat-E-Khuda Kane T.T. ; Levin A. and Ahmed S. (2000). The Effect of birth interval on malnutrition in Bangladeshi infants and young children. J. Biosocial Sci., 32: 289-300.

Murphy S.P.; and Allen L.H. (2003). Nutritional importance of animal source foods. J Nutr. 133, Suppl., 3932S-5S.

Must A.;. Dallal G.E, and Dietz W.H. (1991). Reference data for obesity:85th 95th percentiles of body mass index and triceps skinfold thickness. Am. J. Clin.Nutr., 53: 839 $-46$.

National Center for Health Statics ,NCHS, (www.cdc.gov/nchs/about/major/nhanes/gro wthcharts/zscore/zscore.htm)

Neumann C.G., Bwibo N.O., Murphy S.P., Sigman M., Whaley S.,Allen. L., Guthrie D., Weiss R. and Demment M. (2003). Animal source foods improve dietary quality, micronutrient status, growth and cognitive function in Kenyan school children: background, study design and baseline findings. J Nutr. 133, Suppl., 3941S-3949S.

Nwokoro S. O.,Ifada K., Onochie O. and Olomu J.M. (2006). Anthropometric assessment of nutritional status and growth of 10 - 20 year old individuals in Benin City (Nigeria) Metropolis. Pakistan J. Nutr. 5 (2): 117 21.

PDRHealth(2004).http://pdrhealth.com/drug_info/ nmdrugprofiles/nutsupdrugs/ zin-0281.shtml

Pellett P. and Shadarvian S. (1970). Food Composition Tables for Use in the Middle East. $2^{\text {nd }}$ Ed. Lebanon.

Pourhashemi S. J., Mehdi G. M.,Gholam R. and Banafsheh G.( 2007). Nutritional assessment of macronutrients in primary school children and its association with anthropometric indices and oral health. Pakistan J. Nutr. 6 (6): 687 - 92.
Prentice A. and Bates C.J. (1994). Adequacy of dietary mineral supply for human bone growth and mineralisation. Eur. J. Clin. Nutr. 48, Suppl. 1, 161-77.

Rayhan M. I. and Khan S. (2006). Factors causing malnutrition among under five children in Bangladesh. Pakistan J. Nutr. 5 (6): 558 - 62 .

Rivera J.A., Hotz C.,Gonzalez - Cossio T.; Neufeld L. and Garcia - Guerra A.(2003). The effect of micronutrient deficiency. Nutr. 133, Suppl., 4010S-20S.

Rivera J. and Martorell R. (1988) Nutrition, infection and growth. Part I: Effects of infection on growth. Clin. Nutr. 7: 156-162

Rolland - Cachera M.F. (1993). Body composition during adolescence: methods, limitations and determinants. Hormone Res., 39: 25 - 40.

Sandstead H.H. (1991.) Zinc deficiency. A public health problem? Am J Dis Child 145, 853 9.

Sandstead H.H. (1998). Zinc deficiency and development.http://www.iza.c/omzhe_org/Ar ticles/Art - 02.htm.

Sanghvi U., Thankappan K.R. Sarma P.S. and Sali N.(2001). Assesing Potential Risk factors for child malnutrition in rural Kerala, India. J. Trop. Pediat., 47: 350-5.

Sarraf Z. Goldberg D. Shahbazi M., Arbuckle K. and SalehiM. (2005). Nutritional status of school children in rural Iran.Br.J. Nutr. 94, 390-6.

Satyanarayana K.;Nadamuni N.and Narasinga R B. (1980).Adolescent growth spurt among rural Indian boys in relation to their nutritional status in early childhood. Ann. Hum. Biol. 7, 359 - 65.

Satyanarayana K.; Nadamuni N., Swaminathan M. and Narasinga R.B. (1981). Effect of nutritional deprivation in early childhood on later growth - a community study without intervention. Am. J. Clin. Nutr. 34,1636 - 37.

Simondon K.B., Simondon F.,Simon I. (1998). Preschool stunting age at menarche and adolescent height: a longitudinal study in rural Senegal. Eur. J. Clin. Nutr. 52, 412-18.

Smith L.C. and Haddad L.( 2000). Explaining Child Malnutrition in Developing Countries: A Cross - Country Analysis.' Research Report 111, International Food Policy Research Institute, Washington D.C.

Tanner J.M. (1961). Education and physical growth.Implications of the study of children 
growth for education theory and practice, London University Press.

UNICEF.(1998). State of the world's children, NewYork: Oxford University Press.

Victora C. G. (1992). The association between wasting and stunting: an international perspective. J. Nutr. 122: 1105-10.

Vimleshseth M.D., Sundaram K.R. and Gupta M (1979). Growth reference standards for developing countries. J. Trop. Pediat., 25: 37 -41 .

Waterlow J.C. (1994). Introduction. Causes and mechanisms of linear growth retardation (stunting). Eur. J. Clin. Nutr. 48, Suppl. 1, 14.
Williams S.R. (1985). Nutrition and diet therapy, $5^{\text {th }}$ ed. Mosby, USA.

World Health Organization,WHO,. (1986). Use and interpretation of anthropometric Indicators of Nutritional Status'. Bull. of W.H.O, 64: 71 - 86.

World Health Organisation WHO, (1995). Physical Status: The Use and Interpretation of Anthropometry Geneva:Technical Report Series, 854 pp.

Zahra S. Dena G., Mohammad S. Kristen A. and Moosa S. (2005).Nutritional status of school children in rural Iran. Br. J. Nutri. 94, 390-6.

$$
\begin{aligned}
& \text { تقويم الحالة التغذوية للأطفال في عمر ما قبل المدرسة في الاردن } \\
& \text { عبداللة ياسين عبد الفتاح الرواشدة } \\
& \text { قسم التغذية والصناعات الغذائية _كلبة الزراعة - جامعة مؤتة ـ مؤتة ـ الكرك - ص.ب } 7 \text { ـ الأردن } \\
& \text { ملخص } \\
& \text { درست الحالة التغذوية ل } 194 \text { طفلا ( } 106 \text { ذكر و } 88 \text { أنتى ) من مدينتي الكرك و السلط في الأردن . }
\end{aligned}
$$

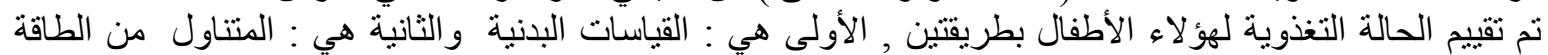

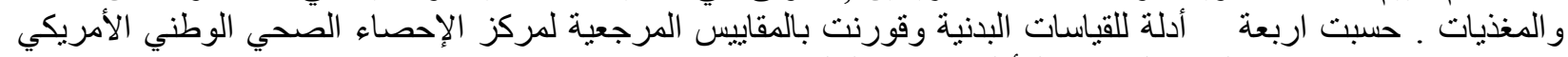

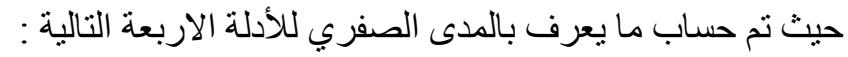

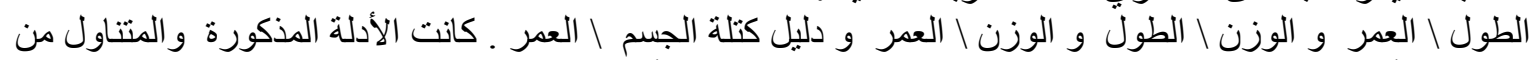

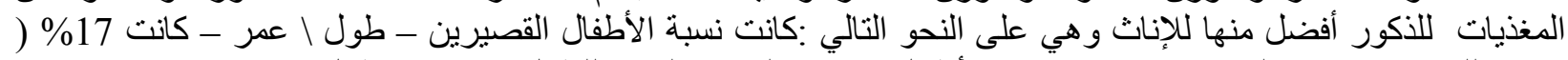

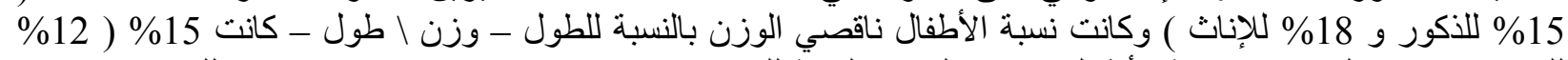

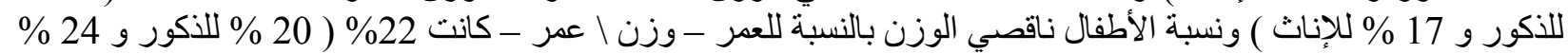

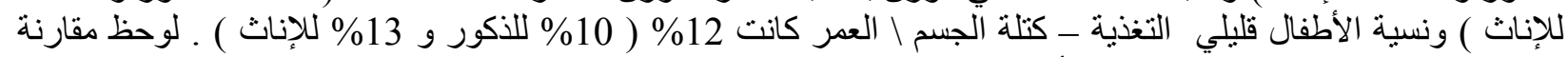

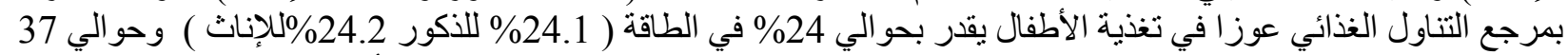

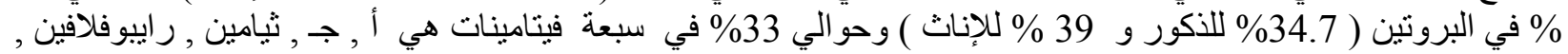

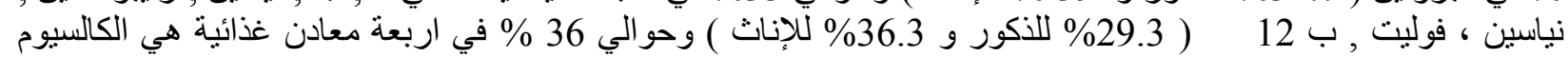

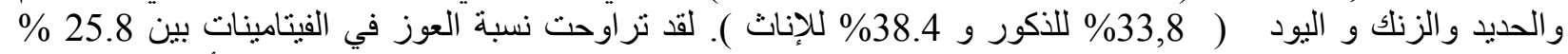

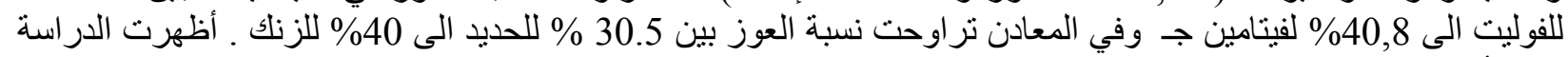

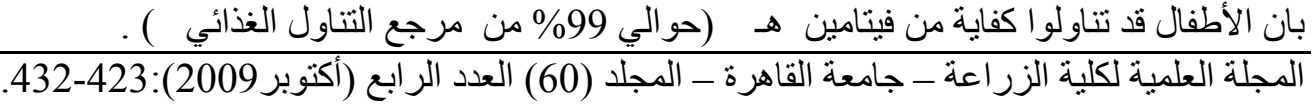

